Global COE Hi-Stat Discussion Paper Series 046

$$
\begin{aligned}
& \text { Research Unit for Statistical } \\
& \text { and Empirical Analysis in Social Sciences (Hi-Stat) }
\end{aligned}
$$

Vertical Foreign Direct Investment:

Evidence from Japanese and U.S. Multinational Enterprises

Kiyoyasu Tanaka

March 2009

Hi-Stat

Institute of Economic Research

Hitotsubashi University 


\title{
Vertical Foreign Direct Investment: Evidence from Japanese and U.S. Multinational Enterprises
}

\author{
Kiyoyasu Tanaka* \\ Institute of Economic Research \\ Hitotsubashi University \\ Email: tanakak@ier.hit-u.ac.jp
}

May 23, 2009

\begin{abstract}
Foreign direct investment (FDI) has rapidly increased in developing countries for the 1990s, but formal evidence for vertical FDI has been surprisingly mixed. This paper empirically reconsiders the factor-proportions hypothesis by exploring the role of host country's relative skill endowments in offshore production of multinational enterprises (MNEs). Using panel data on sales of foreign affiliates by Japanese and U.S. MNEs in the 1990s, I find that relative skill abundance has a large negative impact on Japanese affiliate sales, but little effect on U.S. affiliate sales. Robust to a wide variety of sensitivity checks, the results strongly support vertical FDI in the case of Japanese MNEs, but not U.S. MNEs. Because the dominant view in favor of horizontal FDI against vertical FDI in the previous literature emerged primarily from U.S. data, I empirically demonstrate that data sources on MNEs partly explain weak evidence for vertical FDI.
\end{abstract}

Keywords: Multinational firm, foreign direct investment, skill endowment

JEL classification: F21, F23

\footnotetext{
This paper is a substantially revised version of my dissertation chapter. I am deeply grateful to my professors at the University of Hawaii at Manoa: Theresa Greaney, Sang-Hyop Lee, Ilan Noy, Seiji Naya, and Jack Suyderhoud. I also thank to Jota Ishikawa, Toshiyuki Matsuura, and participants at One-Day Trade Workshop at Hitotsubashi University for valuable comments and suggestions. All remaining errors are my own.
} 


\section{Introduction}

The dramatic rise in foreign direct investment (FDI) is a prominent feature of economic globalization, as global FDI flows increased at a faster pace than international trade and income in recent decades. The global production of multinational enterprises (MNEs) accounted for an estimated $10 \%$ of world output in 2006 , as measured by the value-added of all foreign affiliates as a share of the world GDP (UNCTAD, 2006). It is commonly viewed among trade economists that the rise of multinational activity has been driven partly by a vertical type of FDI that is motivated by low factor costs abroad. Accordingly, the factor-proportions models of international trade have been developed to explain why multinational firms establish production facilities in a low-wage country (Helpman, 1984; Helpman and Krugman, 1985; Markusen, 2002).

A growing number of studies have examined the empirical implication that vertical FDI should arise when countries are different in relative factor endowments. Prior research, including Carr et al. (2001), Braconier et al. (2005a), and Davies (2008), shows that multinational activity is positively related to differences in relative skilled-labor abundance across countries, consistent with vertical FDI. In contrast, another set of research such as Brainard (1993, 1997), Markusen and Maskus (2001, 2002), and Blonigen et al. (2003), finds that multinational production is negatively correlated with relative skill differences. Their findings are limited to supporting horizontal FDI associated with market-access motives. Thus, econometric evidence for vertical FDI is mixed and even contradictory, leading to the dominant view that FDI activity is primarily horizontal. Despite the great interest in vertical fragmentation of production across borders, the empirical importance of the factor-seeking motive of multinational production remains largely inconclusive.

The purpose of this paper is to reconsider the factor-proportions explanation for FDI by investigating the relationship between offshore production of multinational firms and relative skill endowments of host countries. In this paper, I use panel data on sales of foreign affiliates by Japanese and U.S. MNEs for the years 1990, 1995, and 2000. A fairly consistent dataset on 
foreign affiliate sales allows for comparative assessment on the vertical motive of FDI across Japanese and U.S. multinational production in the same set of host countries. Furthermore, this paper employs an instrumental-variables (IV) approach to address potential endogeneity of the host-country supply of skilled labor, which is likely to underestimate vertical FDI. For instance, developing countries may have an incentive to upgrade skill levels of the labor force in order to attract foreign investment. Specifically, I exploit differences in past schooling characteristics as instruments for the contemporaneous level of skilled-labor abundance measured by the educational attainment of the labor force. Thus, I carefully take into account the endogeneity of skilled-labor abundance to obtain a consistent estimate of the effect of skill endowments on multinational activity.

Robust to a wide range of specifications and sensitivity checks, I find that skilled-labor abundance in foreign countries has a significantly negative impact on offshore production by Japanese MNEs. The benchmark results predict that the real sales of Japanese affiliates in manufacturing would decrease by $24.7 \%$ when the average years of schooling in host countries increase by one year. For example, if the labor force in China possessed the equivalent level of educational attainment as in the U.S. for the year 2000, Japanese affiliate sales in China would have been negative, conditional on observables. This suggests that Japanese FDI was strongly encouraged by the factor-cost motive. I also find that the IV estimates of the effect of relative skill abundance are larger in magnitude than the standard regression estimates, implying that the endogeneity produces an upward bias in the estimated impact of host-country skilled-labor on affiliate activities.

In stark contrast to Japanese MNEs, host-country relative skill endowments have no significant effect on foreign affiliate sales by U.S. MNEs. Even after accounting for the endogeneity bias that may underestimate the importance of vertical FDI, the factor-proportions hypothesis is not supported in the U.S. sample. As host-country characteristics in the Japanese and U.S. samples are virtually identical, the different conclusions on the vertical motive of FDI 
are due to the different patterns of Japanese and U.S. multinational production; U.S. affiliate activities are more concentrated in high-wage countries than Japanese affiliate activities. As compared to prior work, my analysis empirically demonstrates that the data source of multinational activity plays a central role in driving empirical evidence for vertical FDI. The implication is that the dominant view in favor of horizontal FDI in the previous literature could result partly from the wide availability of U.S. data on multinational firms.

Section 2 reviews the related literature on vertical FDI. Section 3 discusses an empirical strategy in specification and estimation. Section 4 provides data descriptions of Japanese and U.S. MNE activity and host-country characteristics. Section 5 presents the estimation results with sensitivity analysis. Section 6 concludes.

\section{Empirical Literature on Vertical Foreign Direct Investment}

This section first provides a brief summary of the general-equilibrium approach to FDI to motivate the empirical literature on a vertical motive of multinational production. The theoretical literature has traditionally focused on two forms of multinational production. ${ }^{1}$ Some firms fragment the production process vertically across borders. These firms are vertical MNEs that are headquartered in one country and produce in another country. Other firms establish an identical production process abroad. These firms are horizontal MNEs that maintain both headquarters and plant in one country and an additional plant in another country. Headquarters services such as management, $\mathrm{R} \& \mathrm{D}$, and advertising play a key role in supporting the operation of both MNEs.

A group of theoretical work such as Helpman (1984), Helpman and Krugman (1985), and Markusen (2002) analyzes the role of factor-proportions differences in explaining the

\footnotetext{
${ }^{1}$ Theoretical papers discussed here abstract from the ownership decision of offshore plants. See Helpman (2006) for a survey on international organization of production.
} 
formation of vertical MNEs. ${ }^{2}$ These models predict that offshore production by vertical MNEs is likely to arise when countries are sufficiently different in factor proportions. To illustrate, consider two countries endowed with skilled and unskilled labor. Multinational firms consist of headquarters services and manufacturing production, with headquarters more skilled-labor intensive than production. When countries are similar in relative skill endowments, cross-country differences in the relative price of skilled to unskilled labor is eliminated by international trade. There is no factor-cost incentive for firms in both countries to offshore a production plant.

When one country becomes sufficiently skilled-labor abundant relative to another country, cross-border differentials in the relative skilled-labor cost is not equalized through foreign trade. As a result, factor-cost differentials create an incentive for firms in a relatively skilled-labor-abundant country to establish production facilities in a relatively skilled-labor-scarce country. Headquarters activity that uses skilled labor intensively is located in the country where skilled labor is relatively cheap. Production activity that employs unskilled labor intensively is moved to the country in which unskilled labor is relatively cheap. Consequently, vertical MNEs arise in a single direction to serve consumers at home via offshore production solely because of international differences in relative skill endowments. The supply of unskilled labor in the host country plays a crucial role in attracting vertical investment from the skilled-labor-abundant country.

Another set of theoretical work such as Markusen (1984), Brainard (1997), and Markusen and Venables (1998, 2000), explores a firm's decision between exporting and local production in serving foreign markets to explain the formation of horizontal MNEs. ${ }^{3}$ In contrast to vertical FDI, these models predict that horizontal FDI is likely to occur when countries are similar in relative skill endowments. In these models, a firm consists of a headquarters and a production plant at home. Factor intensities in headquarters and production activities are identical

\footnotetext{
${ }^{2}$ Markusen (2002) combines both vertical and horizontal motives in the model, which is referred to as the knowledge-capital model.

${ }^{3}$ See Helpman et al. (2004) for the horizontal model that incorporates firm heterogeneity.
} 
to rule out vertical fragmentation of production. The firm must decide whether to produce abroad or export by comparing transportation costs of exporting and a plant-specific fixed cost for local production. In the absence of factor-cost motives, horizontal MNEs will arise when gains from economizing on trade costs offset an additional fixed cost of opening an overseas plant. Therefore, the relative skill abundance in a host country provides no direct motive for horizontal FDI. ${ }^{4}$

While market-access and factor-seeking motives are equally prominent reasons for FDI in theory, early empirical studies such as Brainard (1993, 1997), Ekholm (1998), Markusen and Maskus (2001, 2002), provide little support for vertical FDI, but strong evidence in favor of horizontal FDI. Brainard (1993, 1997) investigates the market-access and factor-proportions explanations of multinational production by exploring U.S. data on affiliate sales disaggregated by country and industry for 1989 . She finds that trade costs increase affiliate sales both absolutely and relative to trade, but cross-country differentials in income per worker reduce affiliate activities. Ekholm (1998) provides similar evidence from country-level data on affiliate sales of Swedish multinationals in 1994. Furthermore, Markusen and Maskus $(2001,2002)$ explicitly test the vertical model against the horizontal model for U.S. data on affiliate sales at the country level for 1986-1994. They find that skilled-labor abundance in the host country increases both local and export sales by U.S. affiliates. These findings suggest that horizontal investment is far more important than vertical investment in accounting for aggregate multinational activity.

Aggregate multinational sales arise from both vertical and horizontal reasons for FDI that interact in a complex way. Based on the knowledge-capital model of horizontal and vertical MNEs, Carr et al. (2001) estimate an empirical specification that accounts for complex effects of country characteristics. Using the panel data as in Markusen and Maskus (2002), they find that affiliate production of U.S. firms is attracted to skilled-labor-abundant countries. Blonigen et al. (2003) estimate the modified empirical specification of Carr et al. for U.S. and OECD samples of

\footnotetext{
${ }^{4}$ Markusen (2002) shows that factor-cost differentials indirectly discourage horizontal MNEs, because firms favor exporting over local production for sale in a high-cost market.
} 
MNE activity with the larger country coverage. They show that absolute differences in relative skill endowments reduce affiliate and FDI activity. These results are also inconsistent with the factor-proportions explanation, even after controlling for horizontal reasons.

In response to the dominant evidence for horizontal FDI, a growing number of empirical studies have taken various empirical strategies in search of vertical FDI. A set of empirical work attempts to resolve mixed evidence of the vertical part of the knowledge-capital model. Braconier et al. (2005a) and Davies (2008) modify the empirical specification of Carr et al. and enlarge the country coverage of the MNE data. While these studies provide some evidence for vertical MNEs, their results are sensitive in the sense that relative skill abundance has statistically insignificant effects on FDI activity in some specifications. Another empirical strategy is to directly measure international differences in unskilled labor costs. Braconier, Norbäck, and Urban (2005b) focus on cross-country differences in wage costs by skill level in explaining various affiliate activities of U.S. and Swedish multinationals for 1986-1994. They find that the various types of affiliate production are attracted to a low-wage country for unskilled labor. Hanson, Mataloni, and Slaughter (2005) study trade in intermediate inputs for further processing between foreign affiliates and their parent firms. Using a firm-level sample on U.S. multinationals in 1994, they show that affiliate demand for imported inputs is higher in a country with low unskilled-labor cost. While these findings accord with the factor-proportions implications, it is puzzling that both studies show a positive impact of host-country skilled-labor costs on affiliate activities.

Hanson, Mataloni, and Slaughter (2001) describe a wide range of affiliate activities from detailed information on U.S. multinationals for the years 1982, 1989, and 1998. They present the evidence that trade by foreign affiliates grew in specific countries (Canada and Mexico) and industries (machinery and electronics equipments) for the 1990s. Using a 1994 sample on foreign affiliates by U.S. firms, Yeaple (2003) shows that multinational production in less-skill-intensive sectors is attracted to skilled-labor-scarce countries. These findings support the presence of comparative advantage motives for U.S. outward FDI. To extend the previous 
work that concentrates on U.S. MNEs, Alfaro and Charlton (2007) use a global dataset on foreign subsidiaries in 90 countries and 400 industries. They define vertical FDI as a plant owned by a foreign firm that provides intermediate inputs to its parent firm, and horizontal FDI as a plant that belongs to the same product code as its parent firm. ${ }^{5}$ They find that subsidiaries previously classified as horizontal FDI at the 2-digit industry level are in fact vertical FDI at the 4 digit level; foreign subsidiaries in the specialized input sector for their parents are prevalent in number across developed countries. However, they are not able to observe a trade link between affiliates and parents for a lack of information on affiliate exports. The subsidiaries defined as vertical FDI in their work could actually supply inputs primarily to local producers. In this case, offshore production arises for market-access, rather than factor-seeking, reasons.

This paper adds to the empirical literature in two ways. First, I combine country-level panel data on sales by foreign affiliates of Japanese parent firms with existing U.S. data. Offshore production by Japanese and U.S. MNEs, both of which are headquartered in large and skill abundant countries, are measured in a fairly consistent way. By using an identical group of host countries, this dataset allows for an international comparison on the importance of vertical FDI across Japanese and U.S. MNEs. Since influential papers such as Brainard, (1997), Carr et al. (2001), and Yeaple (2003) draw conclusions almost exclusively from U.S. data, my work provides an important check on possible influences of the U.S. data source in previous evidence against vertical FDI.

Second, this paper improves an empirical strategy on factor-seeking FDI. While many of previous studies exploit a variation in skilled-labor abundance to estimate the factor-cost motive of multinational production, they have paid little attention to a possible bias of the estimated effects of relative skill endowments on MNE activity. It was often (implicitly) assumed

\footnotetext{
${ }^{5}$ Based on the definition of industry classification, the subsidiaries that assemble final goods for export to their parents are likely to be in the same product code as the parents. Despite the vertical nature of such affiliate activity, these subsidiaries seem to be classified as horizontal FDI in their work.
} 
that country-level skill endowments are measured with little error and exogenously determined to identify the parameters of interest. Apparently, there are a number of reasons to indicate the presence of possible bias in the previous estimates for the violation of the assumptions, which is discussed in section 3 . Therefore, this study carefully takes into account the potential endogeneity of skill endowments in a host country by exploiting a variation in some measures of past schooling characteristics as an instrument for the contemporaneous level of educational attainment.

\section{Empirical Framework}

\subsection{Empirical Specification}

To analyze the factor-proportions theory, I adopt an empirical specification designed to estimate the knowledge-capital model in Carr et al. (2001). Their estimating equation is specified to explain affiliate production as a function of home- and host-country characteristics. While the specification includes differences in relative skill endowments to study a vertical motive of multinational activity, it must be modified to meet the nature of my dataset. Since my dataset has only two parent countries, Japan and the U.S., there is little variation in home-country relative skill endowments. Data on the host country account for the dominant variation in relative skill differences across countries. There is little advantage to consider parent-country skill endowments. Focusing on host country's relative skill abundance, I estimate the following equation separately for the Japanese and U.S. samples with a host country $i$ and year $t$ :

$$
A S A L E_{\mathrm{it}}=\beta_{0}+\beta_{1} S K I L L_{\mathrm{it}}+\eta X_{\mathrm{it}}+\Sigma_{\mathrm{t}} \gamma_{\mathrm{t}} \mathrm{T}_{\mathrm{t}}+\varepsilon_{\mathrm{it}}
$$

$A S A L E$ is the real volume of aggregate sales by manufacturing affiliates in each host country, with more than $10 \%$ of their equity stakes owned by parent firms in a home country. SKILL is the measure of the relative supply of skilled labor in each host country. $\mathrm{X}$ is a vector of independent variables that include important host-country characteristics in the investment decision by parent 
firms. These variables serve to disentangle the effects of skill endowments on multinational production from potentially relevant determinants. $T_{t}$ is a set of time fixed effects, with $\gamma_{t}$ a vector of the coefficients. Finally, $\varepsilon$ is an error term.

The purpose of this paper is to obtain an estimate of $\beta_{1}$ in the estimating equation for data on Japanese and U.S. MNEs. The central hypothesis from the factor-proportions model of FDI is that if multinational production is motivated to take advantage of factor-price differentials across borders, then multinational firms would prefer to locate their offshore production in unskilled-labor-abundant countries. Labor-intensive stages of production such as final assembly are moved to a host country that has the lower cost of unskilled workers relative to skilled workers than does a parent country. This implies that affiliate sales should be negatively associated with the skilled-labor abundance in a host country. In other words, a negative sign of the estimate of $\beta_{1}$ shows evidence for vertical FDI.

The alternative hypothesis derived from the market-access explanation for FDI is that if multinationals invest abroad to obtain the access to foreign markets, then factor-cost differentials have no direct impact on the location of their offshore production. The formation of horizontal MNEs is driven not by labor-cost differentials, but by high trade barriers and the large market size. Affiliate sales should not be correlated with the host country's relative skill endowments. In the case of multinationals from highly skill-abundant countries such as Japan and the U.S., a larger value of SKILL implies convergence in relative skill abundance across countries. Skilled-labor abundance could have a positive impact on affiliate sales if horizontal motives are present in data. Thus, a nonnegative sign of the estimate of $\beta_{1}$ can be suggesting evidence for the alternative hypothesis in favor of horizontal FDI.

A set of independent variables, $\mathrm{X}$, are included in equation (1) to control for the other attractiveness of the host market in the location of multinational production. Following Carr et al. (2001), I account for the variables such as GDP, MKP, DIST, TC, and IC. GDP is the level of real GDP in a host country. As firms prefer to locate offshore production in the large market for sale, 
the predict sign for GDP is positive. MKP captures the potential opportunity to export to third markets from a foreign country. If the market potential attracts foreign firms as an export-platform base, MKP would have a positive impact on affiliate sales. On the other hand, if MKP simply reflects the attractiveness of neighboring markets relative to the host country, multinationals may avoid to locate production in the host country with large market potential. MKP would have a negative impact on affiliate sales. The expected sign of MKP is ambiguous.

DIST is the geographic distance between capital cities in home and host countries. Since the distance is a proxy not only for transport costs between countries, but for information and monitoring costs on business operations in the foreign country, the expected sign of DIST is unclear. TC is inward trade cost for measuring trade barriers to imports in a host country. If the data are consistent with horizontal MNEs that economize on trading costs by overseas production, TC should have the positive sign. If the data are consistent with vertical MNEs that supply inputs to foreign assembly, TC should have the negative sign. The predicted sign of TC is not clear. Lastly, IC is investment cost to represent overall investment climate in a host country. As high investment barriers deter the entry of foreign firms to a host market, the predict sign of IC is negative.

\subsection{Estimation Strategy}

The empirical model as specified in equation (1) allows me to disentangle the effects of relative skill endowments on multinational production from those of a wide variety of other country determinants. More precisely, regression analysis with ordinary least squares (OLS) provides an estimate of the coefficient of SKILL, conditional on observable factors such as market opportunities, trade barriers, and investment risk. This paper attempts to shed light on causal effects of skill endowments on multinational production by exploiting a variation in past schooling characteristics as an instrument for the contemporaneous level of host-country skill endowments. This estimation strategy is useful not only for obtaining a consistent estimate of the 
coefficient of SKILL, but for reconsidering a potential bias in previous findings on vertical FDI.

Following the exposition of Wooldridge (2002), SKILL is an endogenous variable when SKILL is correlated with an error term in equation (1). Assuming that available data on relative skill endowments are generated independently from unobserved factors, many of previous empirical studies analyze the linkage between skilled-labor abundance and multinational activity. However, there are a host of reasons to suspect the possible violation of the assumption, which would lead to inconsistency in linear regression. First, reverse causality arises if the supply of skilled labor in a foreign country is affected partly by multinational activity. Slaughter (2002) illustrates several channels through which inward FDI can contribute to skill improvements in the developing countries. The growth of FDI activity since the late 1980s coincided with increased schooling in many developing countries (Barro and Lee, 2000), possibly suggesting an incentive effect of a perceived benefit of FDI on investment in human capital.

Second, measurement error occurs when a proxy variable for skilled-labor abundance includes errors that are correlated with the proxy, but not with the unobserved SKILL variable. Given the tremendous difficulty in practice to make a distinction between skilled and unskilled workers both within and across countries, it follows that the available data for SKILL are likely to be measured with substantial errors. Attenuation bias from the measurement error can reduce the statistical significance of the coefficient of SKILL, which gives rise to bias in favor of horizontal FDI. Finally, omitted-variables bias appears when an error term contains additional variables that are correlated with SKILL. There may be unobserved forms of economic institutions such as a rule of law that create favorable investment climate for foreign investors as well as promote sound development of education systems. As a result, the estimated coefficient of SKILL can be biased upward. While it is difficult to pin down a crucial source of the endogeneity problem among others, it is reasonable to suspect that the SKILL variable suffers from any of possible forms of the endogeneity.

To solve the endogeneity problem, I employ the instrumental-variables (IV) estimation 
with past schooling characteristics as a set of instruments for the current skill intensity of the labor force in a host country. Specifically, I estimate a reduced-form equation for SKILL as follows.

$$
S K I L L_{\mathrm{it}}=\delta_{0}+\delta_{1} P S C H O O L_{\mathrm{i}, \mathrm{t}-10}+\delta_{2} S S C H O O L_{\mathrm{i}, \mathrm{t}-10}+\lambda X_{\mathrm{it}}+\Sigma_{\mathrm{t}} \mu_{\mathrm{t}} \mathrm{T}_{\mathrm{t}}+\mathrm{v}_{\mathrm{it}}
$$

PSCHOOL and SSCHOOL are the average years of primary and secondary schooling of people over age 25 in the previous 10 years, respectively. In the first step, equation (2) is estimated with OLS to obtain the fitted value of SKILL. In the second step, SKILL in equation (1) is replaced with the fitted values of SKILL from the first step, and then the modified equation (1) is estimated with OLS to obtain a consistent estimate of the coefficient of SKILL in the presence of the endogeneity problem.

It is in order to discuss two key assumptions required to identify equation (1) with the IV estimator. First, at least one of the two instruments, PSCHOOL and SSCHOOL, must be sufficiently correlated with SKILL. Conceptually, it is reasonable that the relative supply of skilled labor in a country can be measured with the aggregate stock of human capital obtained through education, which is available for production activities by multinationals. If the average years of schooling are longer for the average adult individuals in one country than for those in another country, then the country is more skilled-labor abundant relative to another country. Given that human capital stock obtained at school represents the abundance of skilled labor, the past level of educational attainment of the population is the best predictor of the current level of educational attainment. Cross-country differences in the average length of schooling in the past period should be reasonably linked to differences in relative skill endowments across countries in the current period.

Specifically, I employ the 10-year previous level of the average years of primary and secondary schooling for the contemporaneous level of the average years of schooling. ${ }^{6}$ This

${ }^{6}$ The 5-year previous level of primary and secondary schooling gives similar results. 
indicates that if the average persons in one country have already spent a longer time at primary and secondary levels than those in another country this year, then the average length of schooling is likely to be longer in the country than in another country in 10 years. Thus, the choice of instruments is based on a conceptually valid link between schooling and SKILL. In addition, it is also crucial in empirical analysis to assess a correlation between the instruments and the potentially endogenous variable. Following Bound, Jaeger, and Baker (1995), I examine instrument relevance by the partial R-squared measures and the F test of the joint significance of PSCHOOL and SSCHOOL in the first-stage regression. A high value of the partial R-squared and a low p-value of the F statistics would be evidence for the instrument relevance.

Second, a set of the instruments must be uncorrelated with an error term in equation (1). The exclusion restriction implied by IV regression is that educational attainment obtained at primary and secondary schools 10 years ago, conditional on the included control variables, have no impact on multinational activity this year. The instruments can have effects on affiliate sales only through skilled-labor endowments. A potential concern is that the past level of primary and secondary schooling of the population could be correlated with the current unobserved characteristics of the host country, which may have a significant direct effect on multinational activity. To the extent that other transmission channels could work, the IV estimate of the effects of SKILL on affiliate sales would capture partly an indirect effect of other determinants. Because the presence of the other transmission channels is not readily apparent, it is not conceptually possible to reject the unintended consequences of the concern about the exclusion restriction. Nevertheless, it is possible to assess the second criterion that the instruments are sufficiently irrelevant to an error term in equation (1) by testing overidentifying restrictions with the J statistic of Hansen (1982). Under the null hypothesis that the instruments are uncorrelated with the error term, the failure to reject the null would provide a check on the instrument irrelevance. 


\section{Data Description}

\subsection{Data on Foreign-Affiliate Activity of Japanese and U.S. firms}

To study a link between outward FDI and skill endowments, this paper uses data on foreign affiliates by Japanese and U.S. parent firms. ${ }^{7}$ The data on Japanese affiliates are taken from the survey on overseas business activities of Japanese firms conducted annually by the Ministry of Economy, Trade, and Industry (METI) in Japan. To examine the stylized facts on Japanese affiliate activities, the METI sends the survey questionnaire directly to the firms that are headquartered in Japan and own more than $10 \%$ of shares of the business enterprise in a foreign country. While the survey covers both manufacturing and non-manufacturing sectors, it excludes parent firms in the finance, insurance, and real estate sectors. A wide variety of data items are included in the survey to measure foreign affiliate characteristics such as country and industry codes, sales and purchases by destination, and employment.

While the METI survey provides detailed information on Japanese multinational activities, it has been recognized that the survey results suffer from low response rates of around $60 \%$, varying samples of parent firms over time, and widely fluctuating sales at the affiliate level. These issues result partly from the fact that reporting to the METI survey is not mandatory for parent firms. The publicly available data provided by the METI are neither sufficiently comparable to foreign-affiliate data from other country sources nor appropriate for rigorous econometric analysis. To overcome dirty data problems, I use the improved data of the METI survey from the Research Institute of Economy, Trade, and Industry (RIETI). ${ }^{8}$ More specifically, Matsuura (2004) exploits individual questionnaires reported by Japanese parent firms to construct panel data on affiliate sales, purchases, and employment at the foreign-affiliate level across countries and industries for the period 1989-2002. After identifying parent and affiliate firms, sector codes, and entry and exit of foreign affiliates in the data, he estimates the missing

\footnotetext{
${ }^{7}$ Data on FDI flows and stocks are more widely available than affiliate data, but imperfect indicator of multinational production with which the factor-proportions hypothesis is concerned.

${ }^{8}$ The RIETI data are available at http://www.rieti.go.jp/database/d08.html.
} 
observations by linear extrapolation for each affiliate. The RIETI provides public access to affiliate data aggregated by country, industry, and year.

For comparison of foreign production by Japanese multinationals with that by U.S. multinationals, I exploit data on foreign affiliates of U.S. nonbank firms from the survey of U.S. direct investment abroad published by the U.S. Bureau of Economics Analysis (BEA). Benchmark surveys are conducted every five years to obtain comprehensive data on all foreign affiliates of U.S. firms. While sample surveys in the non-benchmark years exempt small firms from filing a survey to reduce their reporting burden, the BEA keeps the affiliate coverage over time by estimating their affiliate activities. The BEA survey defines a foreign affiliate as an overseas business enterprise in which a single U.S. firm or person owns $10 \%$ or more of the voting securities. A foreign affiliate is assigned to the sector in which it has the largest percentage of its sales. The BEA provides a number of tabulations on various data items on foreign affiliates aggregated by country and industry.

This paper takes data on foreign affiliate sales from the RIETI and BEA. The data are aggregated over manufacturing sectors to the country level for exploring the relationship between manufacturing production by multinationals and unskilled-labor supply in a host country. Because affiliate sales are denominated in Japanese Yen for the RIETI data and in U.S. dollar for the BEA data, affiliate activities are not directly comparable across these data sources. Thus, Japanese affiliate sales are measured in millions of U.S. dollars using the average of Yen-dollar annual exchange rates in the 1989-2002 period, taken from the International Financial Statistics (IFS) of the International Monetary Fund. ${ }^{9}$ Another issue is that affiliate sales denominated in nominal U.S. dollars are influenced by annual inflation rates. A variation in affiliate sales includes both a change in the price level and a change in real economic activity of foreign affiliates. Thus, affiliate sales are measured in year 2000 U.S. dollars using a U.S. wholesale price index of IFS.

\footnotetext{
9 The period average of exchange rates is used to mitigate an influence from large annual movements in Yen-denominated value of one dollar.
} 
Since the RIETI and BEA survey foreign affiliate activities in a similar way as to concepts and definitions, both datasets provide a fairly consistent measure of real manufacturing production of foreign subsidiaries by Japanese and U.S. MNEs. Compared to statistics on FDI flows and stocks, the affiliate data are much more appropriate for empirical analysis on the scale of the foreign operations of vertical MNEs as predicted by the factor-proportions models. However, it is also important to check practical consistency between the data sources. For this purpose, I compare real sales by Japanese manufacturing affiliates in the U.S. from the RIETI source with those from the U.S. BEA's Foreign Direct Investment in the United States. Although the time-series plots show that Japanese affiliate sales are not identical between the RIETI and BEA data for the period 1989-2002, both data exhibit significantly similar movements in annual changes of affiliate sales, with a correlation coefficient of $0.93 .{ }^{10}$ Thus, the result supports consistency across data sources on Japanese and U.S. multinational activities.

\subsection{Data on Host-country Characteristics}

This paper explores the factor-proportions hypothesis in explaining the pattern of Japanese and U.S. multinational production. While there are various indicators of a country's factor proportions such as capital, labor, and arable land, relative factor endowment is measured by the proportion of skilled labor in the total labor force. Skilled-labor abundance is previously used as a key variable to investigate the relative importance of vertical FDI relative to horizontal FDI. Since it is difficult to disentangle skilled labor from unskilled labor in each country, relative skilled-labor abundance is measured by the educational attainment from Barro and Lee (2000). ${ }^{11}$

\footnotetext{
${ }^{10}$ Although affiliate sales by the RIETI data are higher than those by the BEA data, a systematic difference appears to result from original survey methods. Specifically, BEA survey defines a foreign affiliate owned by a single U.S. firm whereas the METI survey defines a foreign affiliate owned either by a single Japanese firm or jointly by a Japanese parent firm and its other foreign affiliate. In addition, a foreign-affiliate's industry is determined by sectoral sales of the affiliate in the BEA survey, but by subjective judgment of a person who files a report in the METI survey.

${ }^{11}$ Another data source is occupational employment statistics published by the International Labor Organization (ILO). However, the ILO data are less consistent for an international comparison because
} 
Barro and Lee's dataset is constructed by improving census/survey data on schooling from a number of countries in consistent methodology. An improved measure of human capital stock obtained through education with the wide country coverage is extensively used in the literature.

Specifically, this paper measures skilled-labor abundance with the average years of schooling of people over age 25 . However, the education data are available only for every 5 year over the period 1960-2000 whereas MNE data cover the period 1989-2002. The data availability forces me to exploit a variation in educational attainment across countries for the years 1990 , 1995, and 2000. ${ }^{12}$ Additionally, I exploit previous schooling characteristics as instruments for the contemporaneous level of relative skill abundance. Data on past schooling are the average years of primary and secondary schooling of people over age 25 in the previous 10 years from Barro and Lee.

The following data on host-country characteristics are also used. Data on real GDP measured in billions of year 2000 U.S. dollars are taken from the World Development Indicators. ${ }^{13}$ Data on distance measured in kilometers between capital cities of home and host countries come from the International Trade Data website of Raymond Robertson (formerly maintained by Jon Haveman). For data on trade barriers, I use a survey index of national protectionism on imports from the World Competitiveness Report (the World Competitiveness Yearbook for 2000 data) by the International Institute of Management Development. The index ranges from zero to 100 , with a higher number indicating greater perceived trade costs by corporate executives. Finally, data on investment risk in a country are obtained from Euromoney. The risk score is composed of 9 weighted individual scores on investment environment; political

some countries report employment in the 1968 International Standard Classification of Occupations (ISCO) and other countries in the 1988 ISCO. Occupational categories are defined in very different concepts across the schemes, and some countries even switch the reporting scheme in the period of my interest.

${ }_{12}$ Although annual levels in educational attainment can be created by linear interpolation between available years, this method provides little additional variation in skill endowment for regression analysis.

${ }^{13}$ Taiwan GDP data are taken from the Department of Commerce, Taiwan. 
risk $(25 \%)$, economic performance $(25 \%)$, debt indicators $(10 \%)$, debt in default or rescheduled $(10 \%)$, credit ratings $(10 \%)$, access to bank finance $(5 \%)$, access to short-term finance $(5 \%)$, access to capital markets (5\%), and discount on forfaiting (5\%), with higher scores indicating higher country risk.

\subsection{Descriptive Statistics}

Table 1 presents summary statistics of the Japanese and U.S. samples for regression analysis. ${ }^{14}$ There are 110 and 98 observations for the Japanese and U.S. samples, respectively. The difference in the number of observations is partly due to the fact that the data cover 41 host countries for Japanese MNEs and 39 host countries for U.S. MNEs. The U.S. data do not include such countries as Greece, Hungary, and the U.S. for host countries of U.S. affiliates. The Japanese sample excludes Japan as a host country. Because the following results are not affected by including those countries in analysis, the larger samples are used to obtain more efficient estimates. The summary statistics clearly present two key characteristics of my dataset. First, the distribution of foreign affiliate sales is significantly different for Japanese and U.S. multinationals. Second, the host-country characteristics such as relative skill endowments, market size, and inward trade costs are almost identical across the Japanese and U.S. samples. These characteristics imply that any difference in descriptive and econometric analysis across the Japanese and U.S. samples will result primarily from the nature of foreign production by Japanese and U.S. MNEs.

\section{[Table 1 around here]}

Since affiliate data play a key role in the following results, I characterize a pattern of Japanese and U.S. multinational activity with box plots on foreign-affiliate sales for the years 1990, 1995, and 2000. Figure 1 provides additional information on the distribution of affiliate

\footnotetext{
${ }^{14}$ The Appendix contains a list of variable definition and data source, and a list of host countries.
} 
sales to make comparison for an international pattern of Japanese and U.S. multinational activities. There are two prominent features in the figure. The first feature is the wide gap between the maximum and minimum volumes of Japanese affiliate sales, as compared to those of U.S. affiliate sales. This feature indicates that Japanese MNEs have the more dispersed presence of foreign production across countries than do U.S. MNEs. Second, the median values of the Japanese affiliate sales are smaller than those of the U.S. affiliate sales across the years, suggesting that the presence of Japanese MNEs in foreign markets is smaller than that of U.S. MNEs. In other words, U.S. multinationals maintain the deeper and more concentrated presence of foreign production than do Japanese MNEs.

[Figure 1 around here]

Before proceeding with formal econometric analysis, I illustrate the cross-country pattern of multinational activity and relative skill endowments for Japanese and U.S. MNEs. Figures 2-4 presents a relationship between the natural logarithm of affiliate sales relative to GDP and the average years of schooling of the labor force for the years 1990, 1995, and 2000, respectively. Because the volume of multinational sales is strongly influenced by a scale effect of the country size, affiliate activity at the vertical axis is measured by the relative presence of affiliate production in the host economy. All of these figures clearly show a negative relationship between affiliate sales and educational attainment for the Japanese sample, but a positive relationship for the U.S. sample. These results indicate that affiliate sales by Japanese multinationals are relatively larger in more unskilled-labor-abundant countries, consistent with the empirical implication of the factor-proportions hypothesis on vertical MNE activity. In contrast, affiliate sales by U.S. multinationals are relatively larger in more skilled-labor-abundant countries, suggesting that foreign production by U.S. firms is attracted to skilled labor. Because the U.S. is one of the most skill abundant countries, the figures imply that U.S. multinational activity is larger when the U.S. and host countries are similar in relative skill endowments. Thus, 
the U.S. data support the model of horizontal FDI in terms of relative endowments.

[Figure 2-4 around here]

In sum, a simple correlation in the data suggests that Japanese firms may have invested abroad to take advantage of factor-cost differentials across countries whereas U.S. firms may not have established offshore production strongly for factor-cost motives. Evidence for vertical FDI is found in the case of Japanese MNEs, but not U.S. MNEs. It is worthwhile to note that the conclusion is drawn from using the share of affiliate sales in GDP levels as a measure of multinational activity. Defining the variable in such a way is almost equivalent to exploring the role of skill endowments in the cross-country pattern of affiliate sales after controlling for the market-size effects. Obviously, there are a number of other determinants of multinational activity such as trade barriers, investment climate, and government policy. The observed correlation between affiliate sales and education attainment may simply be confounded by omitted third factors. It is a task in the next section to disentangle the effects of skill endowments from other country determinants.

\section{Estimation Results}

\subsection{OLS Regression}

Table 2 presents the results of OLS regression on the determinants of Japanese and U.S. multinational activity. The dependent variable is the natural logarithm of the real volume of sales by manufacturing foreign affiliates of multinationals. The panel data used in estimation include the years 1990, 1995, and 2000 for the Japanese and U.S. samples. The panel dataset is unbalanced for missing observations of some of the independent variables. ${ }^{15}$ Since a

\footnotetext{
${ }^{15}$ Trade cost in a host country has the slightly small country coverage in early years. While excluding the trade-cost variable from the model increases the host-country samples in regression, it is likely to introduce an omitted-variables bias in OLS estimates of the effects of skill endowments on MNE activity. As Carr et al. (2001) use the same survey measure for inward trade barriers, I choose the
} 
Breusch-Pagan test for initial OLS regressions indicates the presence of heteroskedasticity, the following regression results report heteroskedasticity-consistent standard errors.

[Table 2 around here]

Column (1) shows the OLS results for the sample on Japanese MNEs. As suggested by the descriptive analysis, OLS regression gives a significantly negative estimate of the coefficient of host-country skill endowments. This implies that foreign affiliate sales by Japanese firms are likely to decrease with skilled-labor abundance in host countries, conditional on the other observable determinants. In other words, the host country's supply of unskilled-labor would encourage foreign production by Japanese MNEs, consistent with the prediction of the factor-proportions hypothesis. Because the skill-endowment variable is measured by the average years of schooling in the population for the dependent variable of the log of affiliate sales, the size of the coefficient implies that Japanese affiliate sales are predicted to decrease by $24.7 \%$ when the average person in a host country increases the schooling by one more year. ${ }^{16}$ For instance, the average educational attainment for the year 2000 is around 6 years in China and 12 years in the U.S. If China had achieved 6 more years of schooling equivalent to the U.S. level, Japanese affiliate sales were predicted to decrease by whopping $148.2 \%$. Since Japanese affiliates in China had their sales of about 28 billions in U.S. dollar, the calculation implies that the whole volume of their sales could have even disappeared in a ceteris paribus sense.

In contrast to the OLS results for Japanese MNEs, column (2) shows that the relative supply of skilled labor has a statistically insignificant coefficient in OLS specification. Any change in the host country's abundance of skilled labor has no effect on foreign affiliate sales by U.S. firms. As briefly discussed in the literature review, an alternative explanation for the

possible loss of efficiency from overspecification instead of the possible bias of the estimates from underspecification.

${ }^{16}$ The marginal effect is computed by $100 \times(\exp (-0.284)-1)$, which is equal to -24.7 . Taking into account standard errors of the coefficient, the population parameter would range between -0.11 and -0.45 for $95 \%$ of the samples. This indicates that the marginal effect could lie between -10.4 to -36.2 . 
formation of MNE activity against vertical FDI is that horizontal MNEs arise when there are relatively large marginal costs in exporting and lower fixed costs in local production, suggesting no direct role of skill endowments in the location of affiliate production. The U.S. sample is consistent with these implications of horizontal FDI, but provides no support for vertical FDI. The OLS results for U.S. MNE activity also accord well with the previous findings such as Brainard (1997), Carr et al. (2001), and Blonigen et al. (2003). Using the BEA data on outward U.S. affiliate sales in the 1980s and early 1990s, these authors tend to find that U.S. multinationals are attracted to skilled-labor-abundant foreign countries. Since I extend the period coverage up to year 2000, my findings possibly imply that skill abundance became largely irrelevant for the location of more recent U.S. outward FDI.

To statistically test a difference in the coefficients of skill endowments across Japanese and U.S. samples, I include the specification with interaction terms between independent variables and a dummy variable for Japanese MNEs, with the latter entering the model independently. For brevity, column (3) shows only the coefficients of the interaction terms from the new specification estimated with OLS for a pooled sample. As expected from the separate sample regressions, the coefficient of skill endowments in the Japanese sample is smaller by 0.3 than that in the U.S. sample. The test for coefficient differences shows that host-country skill endowments have significantly different impacts on Japanese and U.S. affiliate sales. Combining with the results for the separate samples, it is suggested that Japanese multinationals prefer to locate offshore production in unskilled-labor-abundant countries more strongly than do U.S. multinationals. Although relative skill abundance has no significant influences on the location of U.S. multinational production, U.S. MNEs tend to locate overseas production in more skilled-labor-abundant countries as compared to Japanese MNEs.

Table 2 provides additional insights on important host-country characteristics for multinational production. GDP has the significantly positive coefficients for both Japanese and U.S. data. Offshore production by Japanese and U.S. multinationals is attracted to the large 
market primarily for serving local consumers. Market potential has the significantly negative coefficient in the Japanese sample, indicating that Japanese MNEs tend to avoid the location with potentially large exporting opportunities from a host country. It may simply mean that if neighboring countries are relatively large in economic size, Japanese firms would establish foreign production in the neighboring countries. The coefficients of geographic distance are significantly negative for both Japanese and U.S. data. Multinationals prefer host countries close to their parent countries for various reasons such as information and transportation costs. Trade and investment costs have the negative coefficients, but the statistical significance varies across the samples.

\subsection{Instrumental Variables Regression}

The empirical analysis up to this point has suggested that relative skill abundance in host countries is negatively correlated with Japanese affiliate sales, but has little association with U.S. affiliate sales. These findings are generally consistent with vertical FDI in the case of Japan and with horizontal FDI in the case of the U.S. However, as discussed in the estimation strategy, these results are not sufficient to conclude that host country's unskilled labor plays a causal role in attracting Japanese affiliate activities. The causality link of skill endowments and affiliate production can break down for a number of econometric issues. A possible endogeneity of the SKILL variable in OLS regression is the major concern for analysis. Thus, this section addresses the endogeneity issue by exploiting cross-country differences in past schooling characteristics as instruments for the current skill endowments. If test statistics support instrument relevance for an endogenous variable and its irrelevance for an error term of the structural model, it is reasonable to interpret a significantly negative coefficient of SKILL as suggesting a causal effect of unskilled-labor abundance on MNE activity.

Table 3 presents the results of IV regression for Japanese and U.S. multinational activity. In the case of the Japanese sample, column (1) shows the second-stage regression for the equation 
(1) that replaces SKILL with the fitted value of SKILL in the first-stage regression of column (2). The IV estimate of the coefficient of SKILL is significantly negative with the slightly larger absolute size of the coefficient as compared to the OLS estimate. Taking into account possible bias in the OLS estimate arising from the endogeneity problem, the IV regression suggests that skilled-labor endowments could have stronger negative impacts on Japanese affiliate sales than what implied by the OLS specification.

To check the validity of the IV specification, the first-stage regression supports instrument relevance of the average years of primary and secondary schooling in the previous 10 year. These instruments enter with high significance both individually and jointly in the first-stage regression. The partial R-squared of 0.88 strongly indicates a high correlation between the SKILL variable and the instruments. This implies that potential bias resulting from weak instruments is not a concern in the IV regression. In addition, instrument irrelevance in the structural equation is supported by the relatively small value of Hansen's J statistics for the overidentification test. In other words, there is no strong evidence that the exogenous variables are correlated with the residuals from the second-stage regression. Thus, all of these findings lend considerable support to the conclusion that unskilled-labor abundance in host markets has the significant causality effect on offshore production by Japanese MNEs.

[Table 3 around here]

The IV regression for the U.S. sample is shown in columns (3) and (4). The IV estimate of the coefficient of SKILL is negative, but statistically insignificant. Compared to the OLS estimate, the IV estimate implies that the potential endogeneity of the SKILL variable has an upward pressure on the effect of host-country skill endowments on U.S. affiliate sales. Nevertheless, there is little evidence that foreign unskilled-labor plays a role in the location of U.S. multinational activity. As the tests support instrument relevance in the Japanese sample, the instruments are highly correlated with the SKILL variable in the U.S. regression. In contrast, the 
relatively large value of the Hansen's J statistics does not show the absence of the endogeneity.

However, the Hansen test needs to be interpreted with care. As discussed in Hayashi (2000, p. 218), the J test can be viewed as a specification test to examine whether the model restrictions are valid. To interpret the rejection of the $J$ test as evidence for the endogeneity of the instruments, the underlying assumptions must hold with confidence. In addition, the finite-sample property of the test shows that it is likely to overrejcet the null hypothesis of no endogeneity of the instruments. In the small sample of my dataset, the $\mathrm{J}$ test could indicate correlation between the instruments and an error term even in the absence of the endogeneity problem. Thus, the overidentification test could imply a room for improving the specification in explaining the pattern of U.S. multinational production.

\subsection{Sensitivity Analysis}

Evidence in favor of vertical FDI has been provided with the descriptive statistics and regression results for the Japanese sample, but not for the U.S. While the major concern of the endogeneity of SKILL is already addressed by the IV estimation, the previous regressions could be sensitive to the empirical specification that is closely based on the knowledge-capital model. I introduce some alterations in the specification for robustness checks.

First, the SKILL variable is defined in several ways for the model. Specifically, the SKILL variable measured by the average years of schooling is defined as the natural logarithm to mitigate possible outlier effects of top and bottom countries in educational attainment. The bottom countries such as Indonesia, India, and Brazil had the average 4 years of education in my sample. On the other hand, the duration of education was around 12 years for the top countries such as the U.S., New Zealand, and Canada. Table 4 reports the OLS and IV regressions for the modified specification. The columns (1) and (2) show the significantly negative estimates for the $\log$ of skill endowments in the case of Japan while the columns (7) and (8) give the insignificant coefficients in the case of the U.S. Thus, the results support the conclusion previously made. 
[Table 4 around here]

Next, it was controversial in prior work whether differences in relative skill endowments across countries should be defined as the absolute value (Blonigen et al, 2003). To check the issue, the SKILL variable is defined as the absolute difference in the average years of schooling between parent and host countries. Although there is little variation in parent-country relative skill endowments, the difference variable can serve to explore the implication that vertical FDI should be important when countries become more different in relative endowments. In the Japanese sample, the columns (3) and (4) present the significantly positive coefficients for the absolute skill difference. However, the columns (9) and (10) do not produce any significant coefficients for the U.S. sample. The findings imply that cross-country differences in relative skilled-labor abundance have a positive impact on affiliate sales by Japanese MNEs, but no effects on U.S. affiliate sales. While previous work on the knowledge-capital model focused on the specification of skill differences in resolving weak evidence for vertical FDI (Blonigen et al. 2003; Carr et al. 2003), my findings indicate no prominent role of the absolute difference specification in the results. It is the data source that determines support for vertical FDI.

Finally, skill endowments are measured by the percentage of college graduates in the population taken from Barro and Lee (2000). I exploit differences in the proportion of primaryand secondary-school graduates in the previous 10 years as the instruments for the college graduates. In the case of Japanese MNEs, the OLS result in column (5) shows that the college-graduates variable has the insignificant coefficient. However, the IV regression provides the significantly negative coefficient, possibly indicating that the endogeneity of the college-graduates variable has a strong upward bias in the OLS estimate. Consistent with the previous results, Japanese affiliate sales are smaller in the host countries with the greater share of highly educated workers in the labor force. In the case of the U.S. sample, columns (11) and (12) do not give any significant results. Therefore, my findings suggest that evidence for vertical FDI 
is robust to the variable definition.

In addition to the sensitivity to the variable definition of SKILL, there is also the concern that the schooling instruments used in my analysis could have an effect on MNE activity through omitted variables, other than current skill endowments. To some extent, the concern is mitigated by the absence of evidence by $\mathrm{J}$ statistic for a correlation between the independent variables and the error term in the case of Japanese MNEs. Nevertheless, the failure to find evidence does not necessarily ensure that there are no other transmission channels through which past schooling characteristics could affect current MNE production.

It is useful to assess the validity of IV regressions to the endogeneity resulting from potential omitted-variables bias. To this end, I largely expand the specification with the following variables. First, data on the average corporate tax rates are taken from the University of Michigan World Tax Database to account for the tax effects on the location of multinational production. The database reports statutory corporate income tax rates that measure maximum marginal tax rates faced by companies in each country. ${ }^{17}$ Second, there may be regional effects on the location of MNE production, which could be correlated with the past schooling characteristics. I exploit data from the World Trade Organization to construct an indicator for 3 regional trade agreements: EU, ASEAN Free Trade Area (AFTA), and Mercosur. ${ }^{18}$ Lastly, I control for the geographic contiguity and common language, which are specific to the U.S. sample. The data on common language come from the International Trade Data website of Raymond Robertson.

Table 5 presents the OLS and IV results for the largely expanded specification with Japanese and U.S. data on affiliate sales. In the case of Japanese MNEs, column (1) shows that the OLS estimate of the coefficient of SKILL is significantly negative with the larger absolute magnitude as compared to the OLS estimate obtained from the original specification. Since AFTA

${ }^{17}$ Available at http://www.bus.umich.edu/OTPR/otpr/introduction.htm

18 The European Union (EU) was formed when the Maastricht Treaty was signed in February 1992 and entered into force in November 1993. The ASEAN Free Trade Area (AFTA) was signed in January 1992 and came into force in January 1993. The Common Market of the South (Mercosur) began when the Treaty of Asunción was signed in March 1991. 
has the significantly positive coefficient among the additional control variables, the previous OLS regression might have assigned the effects of ASEAN FTA to those of skill endowments on affiliate sales. The IV regression in column (3) also shows an increase in the absolute size of the coefficient of SKILL. On the other hand, columns (2) and (4) indicate that skill endowments have no significant effect on U.S. affiliate sales, even after accounting for additional control variables that could give rise to an upward bias in the coefficients of SKILL.

[Table 5 around here]

A possible explanation for the upward endogeneity bias is that the past improvement in educational attainment at the primary- and secondary-school levels has generally a beneficial effect on economic growth, which strengthens an incentive for further institutional changes to increase economic gains. Reforms in economic institutions such as administrative procedures, investment rules, and regulatory frameworks could have a positive effect on multinational activity through a reduction in business costs. If the positive effects of institutional upgrading through past developments in the educational attainment are excluded from the IV specification, they could enter the negative effects of the current skill endowments on Japanese MNE activity, giving rise to an upward pressure on the estimates of ceteris paribus effects of SKILL. These arguments imply that the regression analysis tends to downplay the role of host country's unskilled labor on multinational production because the better schooling characteristics in the past period can be likely to contribute to preferable, rather than deteriorating, investment environments for current MNE activity.

\section{Conclusion}

A recent increase in FDI flows is commonly viewed as arising from vertical fragmentation of a firm's production process to take advantage of factor-cost differentials across countries. General equilibrium approach to vertical FDI predicts that vertical MNEs should locate 
unskilled-labor-intensive production in unskilled-labor-abundant countries. Contrary to the theoretical insight, formal evidence for vertical FDI was surprisingly mixed. This paper reconsiders the factor-proportions explanation by using panel data on sales of foreign affiliates by Japanese and U.S. multinationals for the years 1990, 1995, and 2000. Robust to a wide variety of sensitivity checks and endogeneity bias, I find that Japanese affiliate sales are larger in relatively unskilled-labor-abundant countries. One of the conservative estimates predicts that Japanese affiliate sales increase by about $25 \%$ when the average years of schooling of the host-country labor force decrease by one year. On the other hand, there is no evidence that host-country skill endowments influence U.S. affiliate sales. Thus, my analysis provides strong evidence for factor-seeking FDI in the case of Japanese MNEs, but not U.S. MNEs.

The empirical results on the linkage between relative skill endowments and multinational production emerge after carefully controlling for affiliate-data consistency, a variety of host-country characteristics, and endogeneity bias. A distinctive pattern of Japanese and U.S. multinational sales is a crucial source in driving the opposite support for vertical FDI. Since previous empirical work in favor of horizontal FDI tends to focus on U.S. affiliate data, my analysis empirically demonstrate that the data source on multinational activity may play a large role in explaining weak evidence for vertical FDI in the literature. In this sense, my work highlights the importance of an international comparison on the determinants of multinational activity. Additionally, my findings raise a question of why vertical FDI is stronger for Japanese MNEs than U.S. MNEs. While a large number of comparative studies on Japanese and U.S. firms exist, this paper's findings call for further comparative research in the context of vertical FDI activity. 
Table 1. Summary Statistics

\begin{tabular}{lcccccccccc}
\hline & \multicolumn{2}{c}{ No. of observations } & \multicolumn{2}{c}{ Mean } & \multicolumn{2}{c}{ Std. Dev. } & \multicolumn{2}{c}{ Min } & \multicolumn{2}{c}{ Max } \\
Variables & Japan & U.S. & Japan & U.S. & Japan & U.S. & Japan & U.S. & Japan & U.S. \\
\hline \hline ASALE & 110 & 98 & 7.90 & 9.50 & 2.14 & 1.40 & 1.32 & 6.45 & 12.3 & 12.2 \\
SKILL & 110 & 98 & 7.99 & 7.85 & 2.24 & 2.14 & 3.30 & 3.30 & 12.2 & 11.5 \\
PSCHOOL & 110 & 98 & 4.52 & 4.40 & 1.40 & 1.30 & 1.92 & 1.92 & 7.66 & 7.66 \\
SSCHOOL & 110 & 98 & 2.20 & 2.14 & 1.24 & 1.15 & 0.45 & 0.45 & 5.09 & 5.08 \\
GDP & 110 & 98 & 5.44 & 5.53 & 1.13 & 1.08 & 3.65 & 3.78 & 9.19 & 8.47 \\
MKP & 110 & 98 & 1.86 & 1.83 & 0.66 & 0.67 & 0.61 & 0.61 & 3.32 & 3.32 \\
DIST & 110 & 98 & 8.96 & 8.97 & 0.58 & 0.61 & 7.05 & 6.60 & 9.82 & 9.70 \\
TC & 110 & 98 & 31.4 & 32.7 & 12.1 & 12.5 & 10.0 & 10.0 & 64.4 & 64.8 \\
IC & 110 & 98 & 23.1 & 23.0 & 15.5 & 15.6 & 2.17 & 2.17 & 61.5 & 61.5 \\
\hline
\end{tabular}

Table 2. OLS Regression for Determinants of Japanese and U.S. Multinational Activity

Dependent Variable: Log of Real Sales by Manufacturing Foreign Affiliates

\begin{tabular}{|c|c|c|c|}
\hline & $\begin{array}{l}\text { Japanese } \\
\text { Sample } \\
\text { (1) }\end{array}$ & $\begin{array}{l}\text { U.S. } \\
\text { Sample } \\
(2)\end{array}$ & $\begin{array}{c}\text { Coefficient } \\
\text { Difference } \\
\text { (3) }\end{array}$ \\
\hline Skill Endowments & $\begin{array}{c}-0.284^{* * *} \\
(0.084)\end{array}$ & $\begin{array}{c}0.013 \\
(0.061)\end{array}$ & $\begin{array}{l}-0.297^{* *} \\
(0.103)\end{array}$ \\
\hline Log of GDP & $\begin{array}{l}1.097^{* * * *} \\
(0.127)\end{array}$ & $\begin{array}{l}0.899^{* * *} \\
(0.099)\end{array}$ & $\begin{array}{c}0.198 \\
(0.161)\end{array}$ \\
\hline Log of Market Potential & $\begin{array}{c}-1.102^{* * *} \\
(0.247)\end{array}$ & $\begin{array}{l}-0.121 \\
(0.170)\end{array}$ & $\begin{array}{l}-0.981^{* *} \\
(0.301)\end{array}$ \\
\hline Log of Distance & $\begin{array}{l}-1.370^{* * * *} \\
(0.207)\end{array}$ & $\begin{array}{c}-0.462^{* * *} \\
(0.125)\end{array}$ & $\begin{array}{l}-0.908^{* * *} \\
(0.242)\end{array}$ \\
\hline Trade Cost & $\begin{array}{l}-0.020 \\
(0.017)\end{array}$ & $\begin{array}{l}-0.022^{* *} \\
(0.008)\end{array}$ & $\begin{array}{c}0.002 \\
(0.019)\end{array}$ \\
\hline Investment Cost & $\begin{array}{l}-0.037^{*} \\
(0.014)\end{array}$ & $\begin{array}{l}-0.013 \\
(0.011)\end{array}$ & $\begin{array}{l}-0.024 \\
(0.018)\end{array}$ \\
\hline Year 1995 Dummy & $\begin{array}{l}-0.215 \\
(0.372)\end{array}$ & $\begin{array}{c}0.153 \\
(0.223)\end{array}$ & $\begin{array}{l}-0.368 \\
(0.434)\end{array}$ \\
\hline Year 2000 Dummy & $\begin{array}{c}0.344 \\
(0.386)\end{array}$ & $\begin{array}{c}0.216 \\
(0.261)\end{array}$ & $\begin{array}{c}0.128 \\
(0.467) \\
\end{array}$ \\
\hline $\begin{array}{l}\text { No. of Observations } \\
\mathrm{R}^{2}\end{array}$ & $\begin{array}{c}110 \\
0.525\end{array}$ & $\begin{array}{c}98 \\
0.667\end{array}$ & $\begin{array}{c}208 \\
0.635\end{array}$ \\
\hline
\end{tabular}


Table 3. IV Regression for Determinants of Japanese and U.S. Multinational Activity Dependent Variable: Log of Real Sales by Manufacturing Foreign Affiliates

\begin{tabular}{|c|c|c|c|c|}
\hline \multirow{2}{*}{ 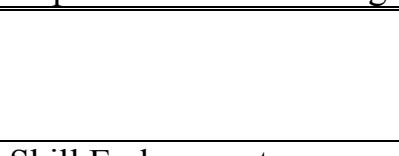 } & \multicolumn{2}{|c|}{ Japanese Sample } & \multicolumn{2}{|c|}{ U.S. Sample } \\
\hline & $\begin{array}{l}2^{\text {nd }} \text { stage } \\
\text { (1) }\end{array}$ & $\begin{array}{l}1^{\text {st }} \text { stage } \\
\text { (2) }\end{array}$ & $\begin{array}{l}2^{\text {nd }} \text { stage } \\
\text { (3) }\end{array}$ & $\begin{array}{l}1^{\text {st }} \text { stage } \\
\text { (4) }\end{array}$ \\
\hline Skill Endowments & $\begin{array}{l}-0.299^{* * *} \\
(0.082)\end{array}$ & & $\begin{array}{l}-0.035 \\
(0.064)\end{array}$ & \\
\hline Log of GDP & $\begin{array}{l}1.099^{* * *} \\
(0.122)\end{array}$ & $\begin{array}{c}0.032 \\
(0.062)\end{array}$ & $\begin{array}{l}0.889^{* * * *} \\
(0.095)\end{array}$ & $\begin{array}{l}-0.108 \\
(0.068)\end{array}$ \\
\hline Log of Market Potential & $\begin{array}{l}-1.104^{* * *} \\
(0.237)\end{array}$ & $\begin{array}{l}-0.297^{* *} \\
(0.105)\end{array}$ & $\begin{array}{l}-0.148 \\
(0.164)\end{array}$ & $\begin{array}{l}-0.413^{* * * *} \\
(0.101)\end{array}$ \\
\hline Log of Distance & $\begin{array}{c}-1.372^{* * * *} \\
(0.197)\end{array}$ & $\begin{array}{l}-0.284^{*} \\
(0.121)\end{array}$ & $\begin{array}{c}-0.498^{* * *} \\
(0.126)\end{array}$ & $\begin{array}{l}-0.190 \\
(0.115)\end{array}$ \\
\hline Trade Cost & $\begin{array}{l}-0.020 \\
(0.016)\end{array}$ & $\begin{array}{l}-0.009 \\
(0.008)\end{array}$ & $\begin{array}{l}-0.022^{* *} \\
(0.008)\end{array}$ & $\begin{array}{l}0.001 \\
(0.007)\end{array}$ \\
\hline Investment Cost & $\begin{array}{c}-0.038^{* *} \\
(0.014)\end{array}$ & $\begin{array}{l}-0.010 \\
(0.007)\end{array}$ & $\begin{array}{l}-0.019 \\
(0.011)\end{array}$ & $\begin{array}{l}-0.022^{* *} \\
(0.007)\end{array}$ \\
\hline Year 1995 Dummy & $\begin{array}{l}-0.214 \\
(0.356)\end{array}$ & $\begin{array}{c}0.191 \\
(0.152)\end{array}$ & $\begin{array}{l}0.140 \\
(0.212)\end{array}$ & $\begin{array}{c}0.161 \\
(0.167)\end{array}$ \\
\hline Year 2000 Dummy & $\begin{array}{c}0.351 \\
(0.375)\end{array}$ & $\begin{array}{c}0.131 \\
(0.160)\end{array}$ & $\begin{array}{l}0.270 \\
(0.257)\end{array}$ & $\begin{array}{c}0.311 \\
(0.163)\end{array}$ \\
\hline Primary School (t-10) & & $\begin{array}{l}0.947^{* * *} \\
(0.042)\end{array}$ & & $\begin{array}{l}0.923^{* * *} \\
(0.053)\end{array}$ \\
\hline Secondary School (t-10) & & $\begin{array}{c}0.901^{* * *} \\
(0.068)\end{array}$ & & $\begin{array}{l}0.885^{* * *} \\
(0.078)\end{array}$ \\
\hline No. of Observations & 110 & 110 & 98 & 98 \\
\hline $\begin{array}{l}\mathrm{R}^{2} \\
\text { Partial } \mathrm{R}^{2}\end{array}$ & & $\begin{array}{l}0.931 \\
0.886\end{array}$ & & $\begin{array}{l}0.924 \\
0.846\end{array}$ \\
\hline $\begin{array}{l}\text { F statistics for } \\
\text { IV Relevance Test }\end{array}$ & & $\begin{array}{l}432.5 \\
(0.000)\end{array}$ & & $\begin{array}{l}228.5 \\
(0.000)\end{array}$ \\
\hline $\begin{array}{l}\text { Hansen's J statistics for } \\
\text { Overidentification Test }\end{array}$ & $\begin{array}{c}2.004 \\
(0.157)\end{array}$ & & $\begin{array}{c}6.199 \\
(0.013)\end{array}$ & \\
\hline
\end{tabular}


Table 4. Sensitivity to Alternative Variable Definitions

Dependent Variable: Log of Real Sales by Manufacturing Foreign Affiliates

\begin{tabular}{|c|c|c|c|c|c|c|c|c|c|c|c|c|}
\hline \multirow[b]{2}{*}{ Estimation } & \multicolumn{6}{|c|}{ Japanese Sample } & \multicolumn{6}{|c|}{ U.S. Sample } \\
\hline & $\begin{array}{l}\text { OLS } \\
\text { (1) }\end{array}$ & $\begin{array}{l}\text { IV } \\
(2)\end{array}$ & $\begin{array}{l}\text { OLS } \\
\text { (3) }\end{array}$ & $\begin{array}{l}\text { IV } \\
(4)\end{array}$ & $\begin{array}{l}\text { OLS } \\
(5)\end{array}$ & $\begin{array}{l}\text { IV } \\
(6)\end{array}$ & $\begin{array}{l}\text { OLS } \\
\text { (7) }\end{array}$ & $\begin{array}{l}\text { IV } \\
(8)\end{array}$ & $\begin{array}{l}\text { OLS } \\
(9)\end{array}$ & $\begin{array}{l}\text { IV } \\
(10)\end{array}$ & $\begin{array}{l}\text { OLS } \\
(11)\end{array}$ & $\begin{array}{l}\text { IV } \\
(12)\end{array}$ \\
\hline Log of Skill & $-1.94^{* *}$ & $-2.16^{* * *}$ & & & & & 0.38 & -0.22 & & & & \\
\hline Endowment & $(0.60)$ & $(0.61)$ & & & & & $(0.43)$ & $(0.46)$ & & & & \\
\hline $\begin{array}{l}\text { Absolute Skill } \\
\text { Difference }\end{array}$ & & & $\begin{array}{l}0.36^{* *} \\
(0.12)\end{array}$ & $\begin{array}{c}0.48^{* * *} \\
(0.14)\end{array}$ & & & & & $\begin{array}{l}-0.01 \\
(0.06)\end{array}$ & $\begin{array}{c}0.03 \\
(0.06)\end{array}$ & & \\
\hline College & & & & & -0.04 & $-0.51^{* *}$ & & & & & 0.02 & -0.29 \\
\hline Graduates & & & & & $(0.03)$ & $(0.19)$ & & & & & $(0.03)$ & $(0.18)$ \\
\hline Observations & 110 & 110 & 110 & 110 & 110 & 110 & 98 & 98 & 98 & 98 & 98 & 98 \\
\hline $\mathrm{R}^{2}$ & 0.52 & & 0.51 & & 0.47 & & 0.67 & & 0.66 & & 0.67 & \\
\hline F statistics & & $\begin{array}{c}232 \\
(0.00)\end{array}$ & & $\begin{array}{c}47.9 \\
(0.00)\end{array}$ & & $\begin{array}{c}5.52 \\
(0.00)\end{array}$ & & $\begin{array}{c}122 \\
(0.00)\end{array}$ & & $\begin{array}{c}229 \\
(0.00)\end{array}$ & & $\begin{array}{c}1.96 \\
(0.14)\end{array}$ \\
\hline $\begin{array}{l}\text { Hansen's J } \\
\text { statistics }\end{array}$ & & $\begin{array}{c}2.43 \\
(0.11)\end{array}$ & & $\begin{array}{c}3.29 \\
(0.06)\end{array}$ & & $\begin{array}{c}2.04 \\
(0.15)\end{array}$ & & $\begin{array}{c}6.44 \\
(0.01)\end{array}$ & & $\begin{array}{c}6.19 \\
(0.01)\end{array}$ & & $\begin{array}{c}0.03 \\
(0.85)\end{array}$ \\
\hline
\end{tabular}

Note: Heteroskedasticity-consistent standard errors are in parentheses, with $* * *, * *$, and $*$ indicating the 1,5 , and 10 percent significance levels, respectively

GDP, MKP, DIST, TC, IC, year dummies, and a constant term are included, but not reported. The null hypothesis for F test is that the instruments jointly have zero coefficients. The null hypothesis for Hansen J statistics is that the instruments are uncorrelated with an error term. P-values are in parentheses for these statistics. College graduates are measured by the percentage of higher school completion in the total population, with the instruments of the percentage of primary and secondary school completion in the previous 10 years. 
Table 5. Sensitivity to Additional Control Variables

Dependent Variable: Log of Real Sales by Manufacturing Foreign Affiliates

\begin{tabular}{|c|c|c|c|c|}
\hline Estimation & $\begin{array}{c}\text { Japanese } \\
\text { Sample } \\
\text { OLS } \\
(1)\end{array}$ & $\begin{array}{l}\text { U.S. } \\
\text { Sample } \\
\text { OLS } \\
(2) \\
\end{array}$ & $\begin{array}{l}\text { Japanese } \\
\text { Sample } \\
\text { IV } \\
\text { (3) }\end{array}$ & $\begin{array}{c}\text { U.S. } \\
\text { Sample } \\
\text { IV } \\
(4)\end{array}$ \\
\hline Skill Endowment & $\begin{array}{c}-0.307^{* * *} \\
(0.083)\end{array}$ & $\begin{array}{c}-0.037 \\
(0.080)\end{array}$ & $\begin{array}{c}-0.319^{* * *} \\
(0.077)\end{array}$ & $\begin{array}{c}-0.073 \\
(0.073)\end{array}$ \\
\hline Log of GDP & $\begin{array}{l}1.260^{* * *} \\
(0.146)\end{array}$ & $\begin{array}{l}1.018^{* * *} \\
(0.131)\end{array}$ & $\begin{array}{l}1.262^{* * * *} \\
(0.136)\end{array}$ & $\begin{array}{l}1.015^{* * *} \\
(0.117)\end{array}$ \\
\hline Log of Market Potential & $\begin{array}{l}-0.596^{*} \\
(0.283)\end{array}$ & $\begin{array}{c}0.254 \\
(0.225)\end{array}$ & $\begin{array}{l}-0.591^{*} \\
(0.264)\end{array}$ & $\begin{array}{c}0.276 \\
(0.208)\end{array}$ \\
\hline Log of Distance & $\begin{array}{c}-1.074^{* * *} \\
(0.230)\end{array}$ & $\begin{array}{c}-0.234 \\
(0.325)\end{array}$ & $\begin{array}{c}-1.078^{* * * *} \\
(0.213)\end{array}$ & $\begin{array}{c}-0.226 \\
(0.294)\end{array}$ \\
\hline Trade Cost & $\begin{array}{l}-0.044^{*} \\
(0.019)\end{array}$ & $\begin{array}{l}-0.032^{* *} \\
(0.011)\end{array}$ & $\begin{array}{l}-0.044^{*} \\
(0.017)\end{array}$ & $\begin{array}{c}-0.032^{* *} \\
(0.010)\end{array}$ \\
\hline Investment Cost & $\begin{array}{l}-0.042^{* *} \\
(0.015)\end{array}$ & $\begin{array}{l}-0.017 \\
(0.014)\end{array}$ & $\begin{array}{c}-0.043^{* *} \\
(0.013)\end{array}$ & $\begin{array}{l}-0.021 \\
(0.012)\end{array}$ \\
\hline Year 1995 Dummy & $\begin{array}{c}-0.413 \\
(0.445)\end{array}$ & $\begin{array}{c}-0.155 \\
(0.256)\end{array}$ & $\begin{array}{c}-0.402 \\
(0.411)\end{array}$ & $\begin{array}{c}-0.143 \\
(0.235)\end{array}$ \\
\hline Year 2000 Dummy & $\begin{array}{c}-0.148 \\
(0.413)\end{array}$ & $\begin{array}{c}-0.147 \\
(0.281)\end{array}$ & $\begin{array}{c}-0.133 \\
(0.383)\end{array}$ & $\begin{array}{c}-0.098 \\
(0.260)\end{array}$ \\
\hline Corporate Tax Rate & $\begin{array}{l}-0.023 \\
(0.021)\end{array}$ & $\begin{array}{c}0.004 \\
(0.016)\end{array}$ & $\begin{array}{l}-0.023 \\
(0.020)\end{array}$ & $\begin{array}{c}0.004 \\
(0.015)\end{array}$ \\
\hline ASEAN Free Trade Area & $\begin{array}{l}2.194^{* * *} \\
(0.398)\end{array}$ & $\begin{array}{l}1.307^{* *} \\
(0.384)\end{array}$ & $\begin{array}{l}2.180^{* * * *} \\
(0.370)\end{array}$ & $\begin{array}{l}1.282^{* * *} \\
(0.359)\end{array}$ \\
\hline Mercosur & $\begin{array}{c}0.170 \\
(0.485)\end{array}$ & $\begin{array}{c}0.758 \\
(0.470)\end{array}$ & $\begin{array}{c}0.172 \\
(0.446)\end{array}$ & $\begin{array}{c}0.795 \\
(0.419)\end{array}$ \\
\hline EU Single Market & $\begin{array}{l}-1.203^{*} \\
(0.511)\end{array}$ & $\begin{array}{l}-0.221 \\
(0.380)\end{array}$ & $\begin{array}{l}-1.231^{*} \\
(0.479)\end{array}$ & $\begin{array}{c}-0.287 \\
(0.347)\end{array}$ \\
\hline Geographic Contiguity & & $\begin{array}{c}0.563 \\
(0.658)\end{array}$ & & $\begin{array}{c}0.592 \\
(0.588)\end{array}$ \\
\hline Common Language & & $\begin{array}{c}0.397 \\
(0.261)\end{array}$ & & $\begin{array}{c}0.438 \\
(0.246)\end{array}$ \\
\hline $\begin{array}{l}\text { Observations } \\
\mathrm{R}^{2}\end{array}$ & $\begin{array}{c}94 \\
0.661\end{array}$ & $\begin{array}{c}83 \\
0.725\end{array}$ & 94 & 83 \\
\hline $\begin{array}{l}\text { F statistics for } \\
\text { IV Relevance Test } \\
\text { Hansen's J statistics for } \\
\text { Overidentification Test }\end{array}$ & & & $\begin{array}{c}496.2 \\
(0.000) \\
1.151 \\
(0.283)\end{array}$ & $\begin{array}{c}283.0 \\
(0.000) \\
3.849 \\
(0.049)\end{array}$ \\
\hline $\begin{array}{l}\text { Note: Heteroskedasticity-con } \\
5 \text {, and } 10 \text { percent significanc } \\
\text { F test is that the instruments } \\
\text { the instruments are uncorrela }\end{array}$ & $\begin{array}{l}\text { standard } \\
\text {, respecti } \\
\text { have zero } \\
\text { h an error }\end{array}$ & lues ar & $\begin{array}{l}* * *, * *, \mathrm{a} \\
\text { ported. } \mathrm{Th} \\
\text { sis for } \mathrm{Ha} \\
\text { ses for th }\end{array}$ & $\begin{array}{l}\text { ating the } 1 \text {, } \\
\text { othesis for } \\
\text { istics is that } \\
\text { cs. }\end{array}$ \\
\hline
\end{tabular}


Figure 1. Pattern of Japanese and U.S. Multinational Sales By Year and Home Country

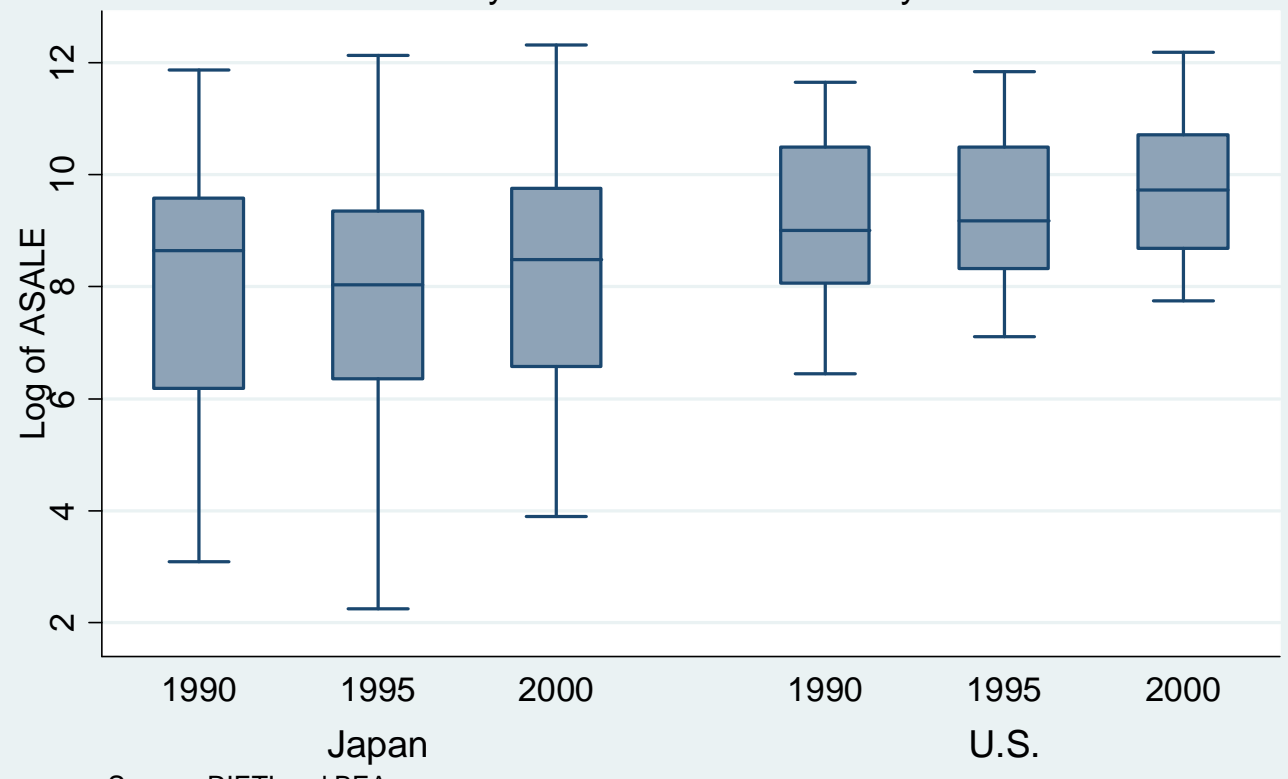

Source: RIETI and BEA

Figure 2. Affiliate Sales and Relative Skill Endowments for Year 1990 By Home Country

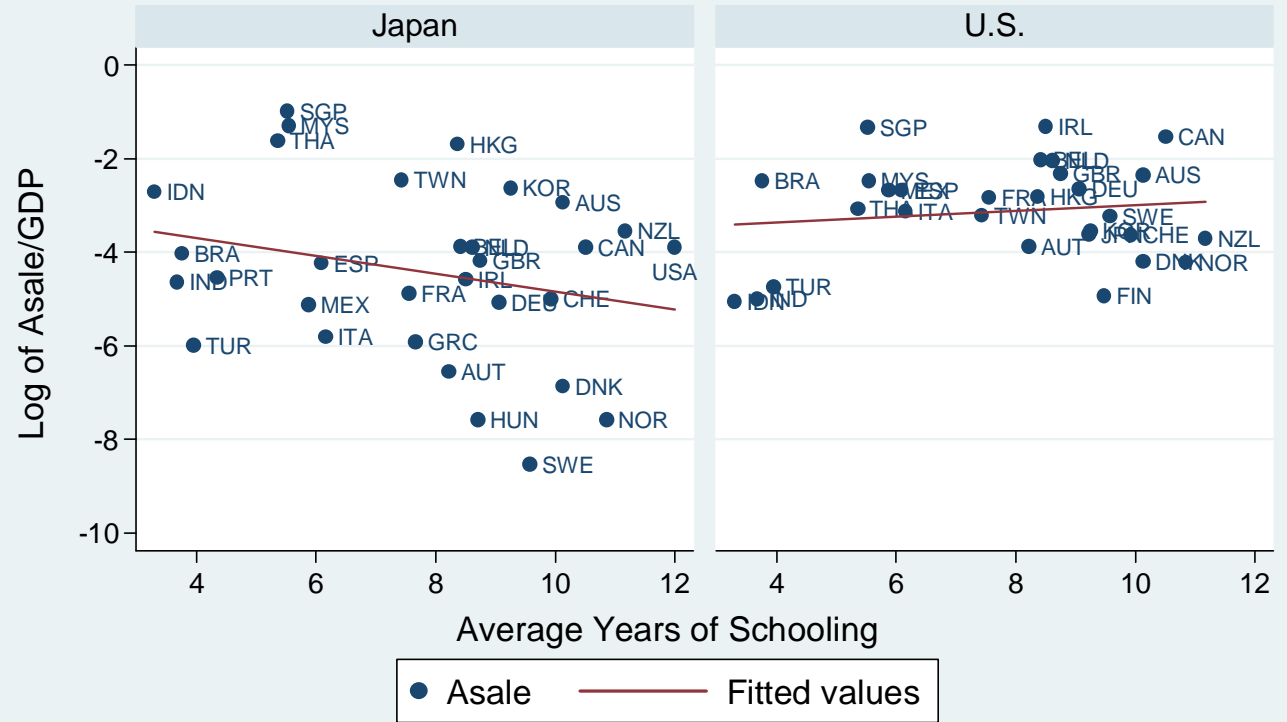

Source: RIETI, BEA, and Barro and Lee(2000)

Note: Asale and GDP are measured in billions of U.S. dollars. 
Figure 3. Affiliate Sales and Relative Skill Endowments for Year 1995 By Home Country

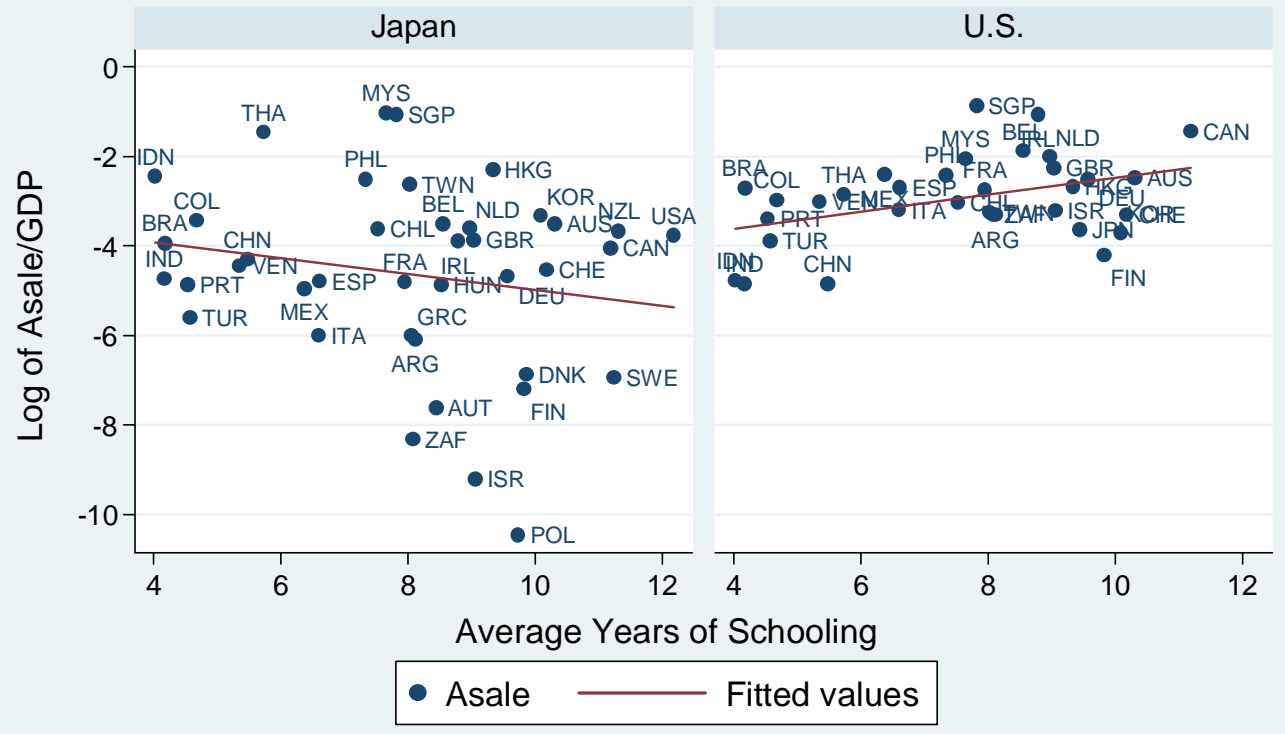

Source: RIETI, BEA, and Barro and Lee(2000)

Note: Asale and GDP are measured in billions of U.S. dollars.

Figure 4. Affiliate Sales and Relative Skill Endowments for Year 2000 By Home Country

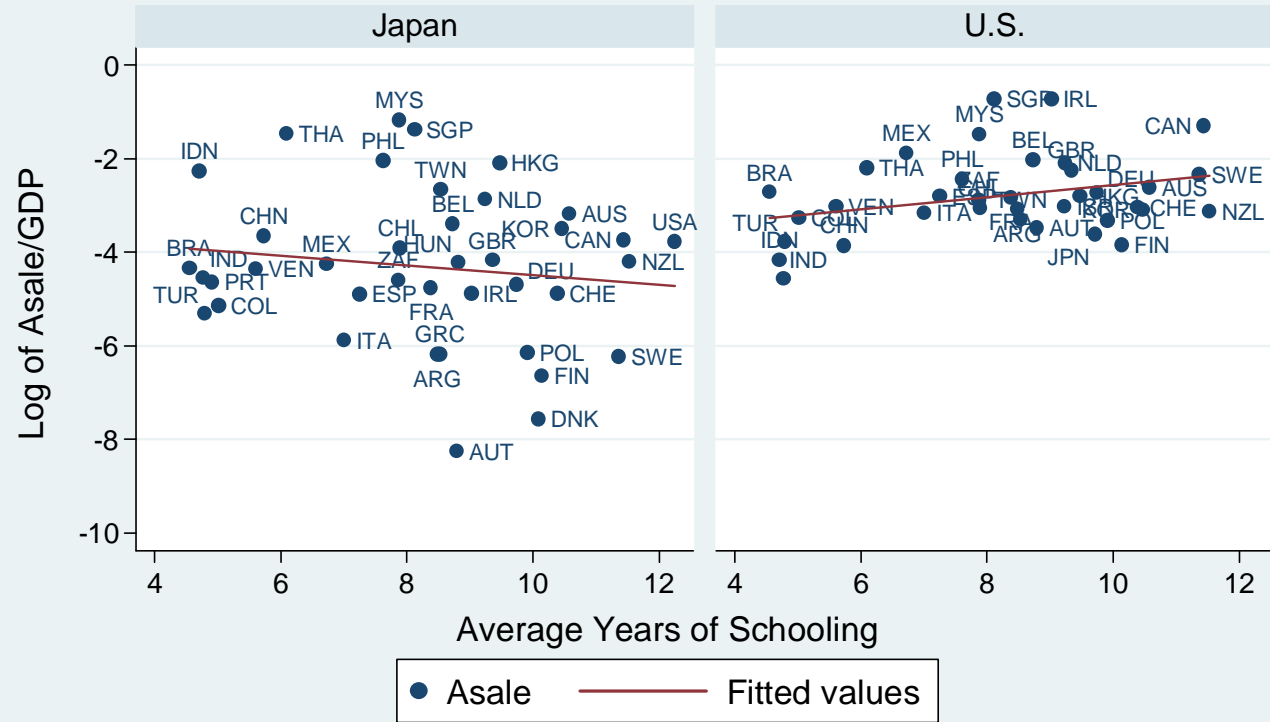

Source: RIETI, BEA, and Barro and Lee(2000)

Note: Asale and GDP are measured in billions of U.S. dollars. 


\section{Appendix}

Table A1: Variable Definition and Data Source

\begin{tabular}{|c|c|c|}
\hline Variable & Definition & Source \\
\hline ASALE & $\begin{array}{l}\text { Log of aggregate sales of all manufacturing } \\
\text { affiliates in each country measured in year } \\
2000 \text { U.S. dollars, using IFS data on a U.S. } \\
\text { wholesale price index and the period } \\
1989-2002 \text { average of yen/dollar exchange } \\
\text { rates }\end{array}$ & $\begin{array}{l}\text { Japanese affiliate data from } \\
\text { the Research Institute of } \\
\text { Economy, Trade and Industry; } \\
\text { U.S. affiliate data from Bureau } \\
\text { of Economic Analysis, U.S. } \\
\text { Department of Commerce }\end{array}$ \\
\hline SKILL & $\begin{array}{l}\text { Average years of schooling of people over } \\
\text { age } 25\end{array}$ & \\
\hline PSCHOOL & $\begin{array}{l}\text { Average years of primary schooling of } \\
\text { people over age } 25 \text { in the previous } 10 \text { years }\end{array}$ & Barro and Lee (2000) \\
\hline SSCHOOL & $\begin{array}{l}\text { Average years of secondary schooling of } \\
\text { people over age } 25 \text { in the previous } 10 \text { years }\end{array}$ & \\
\hline GDP & $\begin{array}{l}\text { Log of real GDP in billions of year } 2000 \\
\text { U.S. dollars }\end{array}$ & \\
\hline MKP & $\begin{array}{l}\text { Log of sum of distance-weighted GDP } \\
\text { levels of all markets excluding host GDP }\end{array}$ & World Development Indicator \\
\hline DIST & $\begin{array}{l}\text { Log of distance in kilometers between } \\
\text { capital cities in home and host countries }\end{array}$ & Raymond Robertson Website \\
\hline $\mathrm{TC}$ & $\begin{array}{l}\text { Ordinal index of protectionism, ranging } \\
\text { from } 0 \text { to } 100\end{array}$ & $\begin{array}{l}\text { World Competitiveness } \\
\text { Yearbook }\end{array}$ \\
\hline IC & $\begin{array}{l}\text { Ordinal index of overall country risk, } \\
\text { ranging from } 0 \text { to } 100 \text {; overall risk score } \\
\text { consists of } 9 \text { weighted individual scores } \\
\text { including political risk }(25 \%) \text {, economic } \\
\text { performance }(25 \%) \text {, debt indicators }(10 \%) \text {, } \\
\text { debt in default or rescheduled }(10 \%) \text {, credit } \\
\text { ratings }(10 \%) \text {, access to bank finance }(5 \%) \text {, } \\
\text { access to short-term finance }(5 \%) \text {, access to } \\
\text { capital markets }(5 \%) \text {, and discount on } \\
\text { forfaiting }(5 \%)\end{array}$ & Euromoney \\
\hline
\end{tabular}


Table A2: Country List and Code

\begin{tabular}{llllll}
\hline \multicolumn{1}{c}{ Country } & Code & Sample & \multicolumn{1}{c}{ Country } & Code & Sample \\
\hline \hline Argentina & ARG & (JP, US) & Japan & JPN & ( , US) \\
Australia & AUS & (JP, US) & Malaysia & MYS & (JP, US) \\
Austria & AUT & (JP, US) & Mexico & MEX & (JP, US) \\
Belgium & BEL & (JP, US) & Netherlands & NLD & (JP, US) \\
Brazil & BRA & (JP, US) & New Zealand & NZL & (JP, US) \\
Canada & CAN & (JP, US) & Norway & NOR & (JP, US) \\
Chile & CHL & (JP, US) & Philippines & PHL & (JP, US) \\
China & CHN & (JP, US) & Poland & POL & (JP, US) \\
Colombia & COL & (JP, US) & Portugal & PRT & (JP, US) \\
Denmark & DNK & (JP, US) & Singapore & SGP & (JP, US) \\
Finland & FIN & (JP, US) & South Africa & ZAF & (JP, US) \\
France & FRA & (JP, US) & South Korea & KOR & (JP, US) \\
Germany & DEU & (JP, US) & Spain & ESP & (JP, US) \\
Greece & GRC & (JP, $)$ & Sweden & SWE & (JP, US) \\
Hong Kong & HKG & (JP, US) & Switzerland & CHE & (JP, US) \\
Hungary & HUN & (JP, ) & Taiwan & TWN & (JP, US) \\
India & IND & (JP, US) & Thailand & THA & (JP, US) \\
Indonesia & IDN & (JP, US) & Turkey & TUR & (JP, US) \\
Ireland & IRL & (JP, US) & United Kingdom & GBR & (JP, US) \\
Israel & ISR & (JP, US) & United States & USA & (JP, $)$ \\
Italy & ITA & (JP, US) & Venezuela & VEN & (JP, US) \\
\hline
\end{tabular}

Note: JP and US indicate that Japanese and US samples have a country for at least one year, respectively. 


\section{References}

Alfaro, Laura and Andrew Charlton. 2007. "Intra-Industry Foreign Direct Investment." NBER Working Paper 13447.

Barro, Robert J. and Jong-Wha Lee. 2000. "International Data on Educational Attainment: Updates and Implications." Center for International Development Working Paper.

Blonigen, Bruce A., Ronald B. Davies, and Keith Head. 2003. "Estimating the Knowledge-Capital Model of the Multinational Enterprise: Comment." American Economic Review, 93:3, pp. 980-94.

Bound, John, David A. Jaeger, and Regina M. Baker. 1995. "Problems with Instrumental Variables Estimation When the Correlation between the Instruments and the Endogenous Explanatory Variable Is Weak." Journal of the American Statistical Association, 90:430, pp. 443-50.

Braconier, Henrik., Pehr-Jhon. Norbäck, and Dieter Urban. 2005a. "Reconciling the Evidence on the Knowledge Capital Model." Review of International Economics, 13:4, pp. 770-86.

Braconier, Henrik, Pehr-Johan Norbäck, and Dieter Urban. 2005b. "Multinational Enterprises and Wage Costs: Vertical FDI Revisited." Journal of International Economics, 67:2, pp. 446-70.

Brainard, S. Lael. 1993. "An Empirical Assessment of the Factor Proportions Explanation of Multinational Sales." NBER Working Paper 4583.

Brainard, S. Lael. 1997. "An Empirical Assessment of Proximity-Concentration Trade-off between Multinational Sales and Trade." American Economic Review, 87:4, pp. 520-44.

Carr, David L., James R. Markusen, and Keith E. Maskus. 2001. "Estimating the Knowledge-Capital Model of the Multinational Enterprise." American Economic Review, 91:3, pp. 693-708.

Carr, David L., James R. Markusen, and Keith E. Maskus. 2003. "Estimating the Knowledge-Capital Model of the Multinational Enterprise; Reply." American Economic Review, 93:3, pp. 995-1001.

Davies, Ronald B. 2008. "Hunting High and Low for Vertical FDI." Review of International Economics, 16:2, pp. 250-67.

Ekholm, Karolina. 1998. "Proximity Advantages, Scale Economies, and the Location of Production," in The geography of multinational firms. Pontus Braunerhjelm and Karolina Ekholm eds: Boston: Kluwer Academic, pp. 59-76.

Hansen, Lars P. 1982. "Large Sample Properties of Generalized Method of Moment Estimators." Econometrica, 50, pp. 1371-96.

Hanson, Gordon H., Raymond J. Mataloni, Jr., and Matthew J. Slaughter. 2001. "Expansion Strategies of U.S. Multinational Firms," in Brookings Trade Forum, 2001. Dani, Rodrik and Susan, Collins eds: Brookings Institution Press, pp. 245-94.

Hanson, Gordon H., Raymond J. Mataloni, Jr., and Matthew J. Slaughter. 2005. "Vertical Production Networks in Multinational Firms." Review of Economics and Statistics, 87:4, pp. 664-78.

Hayashi, Fumio. 2000. Econometrics: Oxford: Princeton University Press.

Helpman, Elhanan. 1984. "A Simple Theory of International Trade with Multinational Corporations." Journal of Political Economy, 92:3, pp. 451-71.

Helpman, Elhanan. 2006. "Trade, FDI, and the Organization of Firms." Journal of Economic Literature, 44:3, pp. 589.

Helpman, Elhanan and Paul R. Krugman. 1985. Market structure and foreign trade : increasing returns, imperfect competition, and the international economy. Cambridge, Mass.: MIT Press.

Helpman, Elhanan, Marc J. Melitz, and Stephen R. Yeaple. 2004. "Export versus FDI with Heterogeneous Firms." American Economic Review, 94:1, pp. 300-16.

Markusen, James R. 1984. "Multinationals, Multi-plant Economies, and the Gains from Trade." Journal of International Economics, 16:3-4, pp. 205-26.

Markusen, James R. 2002. Multinational firms and the theory of international trade. Cambridge, Mass.: MIT Press. 
Markusen, James R. and Keith E. Maskus. 2001. "Multinational Firms: Reconciling Theory and Evidence," in Topics in Empirical International Economics: A Festschrift in Honor of Robert E. Lipsey. Magnus Blomstrom and Linda S. Goldeberg eds. Chicago: University of Chicago Press, pp. 71-95.

Markusen, James R. and Keith E. Maskus. 2002. "Discriminating among Alternative Theories of the Multinational Enterprise." Review of International Economics, 10:4, pp. 694-707.

Markusen, James R. and Anthony J. Venables. 1998. "Multinational Firms and the New Trade Theory." Journal of International Economics, 46:2, pp. 183-203.

Markusen, James R. and Anthony J. Venables. 2000. "The Theory of Endowment, Intra-industry and Multi-national Trade." Journal of International Economics, 52:2, pp. 183-203.

Matsuura, Toshiyuki. 2004. "Estimating Economic Activity, Sales, and Procurements of the Overseas Affiliates of Japanese Multinational Firms (in Japanese)." Keizai Toukei Kenkyu, 32:4, pp. 1-16.

Slaughter, Matthew J. 2002. "Does Inward Foreign Direct Investment Contribute to Skill Upgrading in Developing Countries?" SCEPA Working Papers.

United Nations Conference on Trade and Development. World Investment Report 2006. New York: United Nations.

Wooldridge, Jeffrey M. 2002. Econometric analysis of cross section and panel data: Cambridge: MIT Press.

Yeaple, Stephen R. 2003. "The Role of Skill Endowments in the Structure of U.S. Outward Foreign Direct Investment." Review of Economics and Statistics, 85:3, pp. 726-34. 